\title{
Commercialize the Cultivation of Yellow Pumpkin Plants
}

\author{
Haryono $^{1}$, Endang Siswati ${ }^{2}$, Indah Epriliati ${ }^{3}$, Indra P P Salmon ${ }^{4}$ \\ ${ }^{1}$ Department of Economic Development, Faculty of Economics and Business, University of Bhayangkara, Surabaya, \\ Indonesia \\ ${ }^{2}$ Department of Management, Faculty of Economics and Business, University of Bhayangkara, Surabaya, Indonesia \\ ${ }^{3}$ Department of food technology, Faculty of agricultural technology, Widya Mandala University, Surabaya, Indonesia \\ ${ }^{4}$ Department of Public Administration, Faculty of Social and Political Science, University of Bhayangkara, Surabaya, \\ Indonesia
}

Correspondence: Haryono, Research and Community Services Institution (LPPM), University of Bhayangkara Surabaya, Indonesia. E-mail: haryono@ubhara.ac.id

\author{
Received: December 21, 2019 Accepted: January 16, 2020 Online Published: February 20, 2020 \\ doi:10.5539/res.v12n1p66 \\ URL: https://doi.org/10.5539/res.v12n1p66
}

\begin{abstract}
This paper aims to explain the highly prospect and opportunity of yellow pumpkin commercialized and its indicate variable behind the lows interest of making it as the main crop by farming society. Cultivation technical approach used in identifying cultivating system of yellow pumpkin and use SWOT analysis to develop the strategy. Analyzing business feasibility commercialization of the cultivation of yellow pumpkin income calculations every harvest based on the primary data by the census of 9 sample group of farmers, observation, and in-depth interviews some key informants. The result of this research show that cultivation system of yellow pumpkin in Majasem Village do potential for cultivated commercially based on the mountain areas the mount of Northern Lawu with a production capacity 180.000 tons. Majasem Village qualified planting cultivation yellow pumpkin although using the simple and planting patterns the midst of rice, corn and soybean. Potential development cultivation yellow pumpkin in the future identified based on internal and external factors have a great capital opportunity to commercialization in supporting industrialization food and drink. Business feasibility in commercialization by requiring investment IDR 3.579.800 and IDR 6.211.667 at operational cost can produce income IDR 8.550 .000 per harvest or IDR 2.338.333 per month with long turning capital during 2 months.
\end{abstract}

Keywords: commercialization, opportunity, socio-ecoonomic, yellow pumpkin

\section{Introduction}

Pumpkin are agriculture product that can be used as an alternative food source. Fiber on pumpkin are great to maintain health. Various nutrition on pumpkin make it favorable food source. Not only used on fasting month on islamic culture in Indonesia, pumpkin also used as ingredients of various processed food. Pumpkin also known internationally, and iconic of halloween in United States. Pumpkin cultivation are considered easy, even without incentive treatment pumpkin can have good growth and produce its fruit. Pumpkin fruit have various nutrient like vitamin A, vitamin B, vitamin C, carbohydrate, fiber, folic acid, iron, protein, calcium. (Gardjito, 2006; Hedrasty, 2011; Shahidan et al, 2014; Aimi Fadzirul et al, 2018)

So far, the level of need from society for pumpkin commodity are quite high. Business opportunities of pumpkin cultivation are more promising. People are cultivating pumpkin on country. Cultivation method of pumpkin are not that difficult. From its propagation, pumpkin are easy to treat and its yield are regarded as high. The prospect of pumpkin cultivation development on large scale and agribusiness oriented are widely open. Few factor that support this are: (1) Indonesia have a chance to become world pumpkin exporter because pumpkin can grow on Indonesia soils easily; (2) indonesian farmer have experience on pumpkin cultivating; (3) return of investment from this business are generally quick; (4) pumpkin are tolerant to many kind of marginal land, even sand; (5) product from pumpkin are not easily degraded and damaged, even though its saved for long time; (6) need of pumpkin will always rise, and (7) society are generally use organic for industrial product. (Perez \& Gomez, 2010; Sidik, 2015; Ahmad \& Khan, 2019; Kelley \& Langston Jr., 2017)

Pumpkin cultivation pumpkin and its product processing are chain process that inseparable. Generally pumpkin farmer cultivation process starts from clearing land, spreading seeds, planting, nurturing, and harvesting. They also take part in product processing till they are ready to be sold (Negi \& Anand, 2014; King et al, 2010). (Department of Agriculture of Kabupaten Magetan, 2015) Main problem are: (i) Low productivities and product quality; and (ii) pumpkin market are 
depend on season. The problem occur because of conventional method of pumpkin cultivation and the pumpkin product industry are generally micro industry and close to non-existent. Nutrient from pumpkin thay can be used on pharmacy, cosmetic, food coloring, leather craft, and traditional food (Shahidan et al, 2014; Iwo et al, 2014; Hwa Keen et al, 2016; Pongjanta et al, 2006). These show that prospect from pumpkin are great, but society still cultivate and produce pumpkin as intercropped plant only and yet to be commercialized (Kit Yok et al, 2015; Kamarubahrin et al, 2018). This study aimed at 1) to identify pumpkin business system profile, potential and weakness at cultivation of pumpkin in future; 2) to analyze properness of commercialized of pumpkin cultivation.

\section{Method}

Main focus and research type used in the research design is qualitative descriptive. To give a view concerning commercialization of pumpkin in Majasem village, Kendal, this research are implemented on Majasem village, Kendal district, Ngawi regency. Research period are 4 (four) month starting on May till September 2019. Secondary data obtained from the information availability on Majasem village government. To support the research, primary data are gathered from sample using census, observation, interview, and questionnaire to head of farmer group, which consist of 9 people. Several key information are village government, which represented by Village Secretary, Village Consultative Board (BPD), Village Society Empowerment Institution (LPMD), RT/RW, Youth Organization, researcher also use academic discussion (researcher as key informant) and related parties that appointed and considered to have competence and authority to provide information or data. (Agusta et al, 2014; Pitono et al, 2016)

In identifying pumpkin business system cultivation technique approached are used such as growth requirement, land preparation, cropping patterns, treatment patterns and post harvest (Ahmad \& Khan, 2019). (Magetan Regency Department of Agriculture, 2015) Variable used as determinant on this pumpkin business strategy research are internal strength and weakness with opportunity and threats are considered are external factor (Gürel \& Tat, 2017). To analyze the business of commercialized pumpkin cultivation, variable that used on profit calculation are investments cost, fixed costs, variable costs. (Horne \& Wachowicz, 2013; Dugguh et al, 2018) Another important variable that used are post harvest marketing line on pumpkin cultivation. (Budiarto, 2011) Data processing on this research are describing data and presented on table and then analyzed with SWOT, profit analysis to calculate economic profit level on pumpkin. (Rangkuti, 2013; Horne \& Wachowicz, 2013; Gürel \& Tat, 2017) Profit analysis used with distribution chain. (Rachmania et al, 2016) Whole data analysis are done through several stages, which are data gathering, data reduction, data presentation, and drawing conclusions. (Singarimbun \& Effendi, 2008)

\section{Result}

\subsection{General Description on Majasem Village Kendal, Ngawi Regency}

Majasem village located on Lawu mountain slope, based on hilly tophography and are on 400-689 masl. Majasem village, Kendal, Ngawi regency (B) position are 262 56' 27.24" (West of) from Surabaya (A) with straight line 143.87 $\mathrm{km}$ (Red Line). Surabaya-Ngawi distance is $279 \mathrm{~km}$ (Blue line is estimated 3 hours 14 minutes drive).

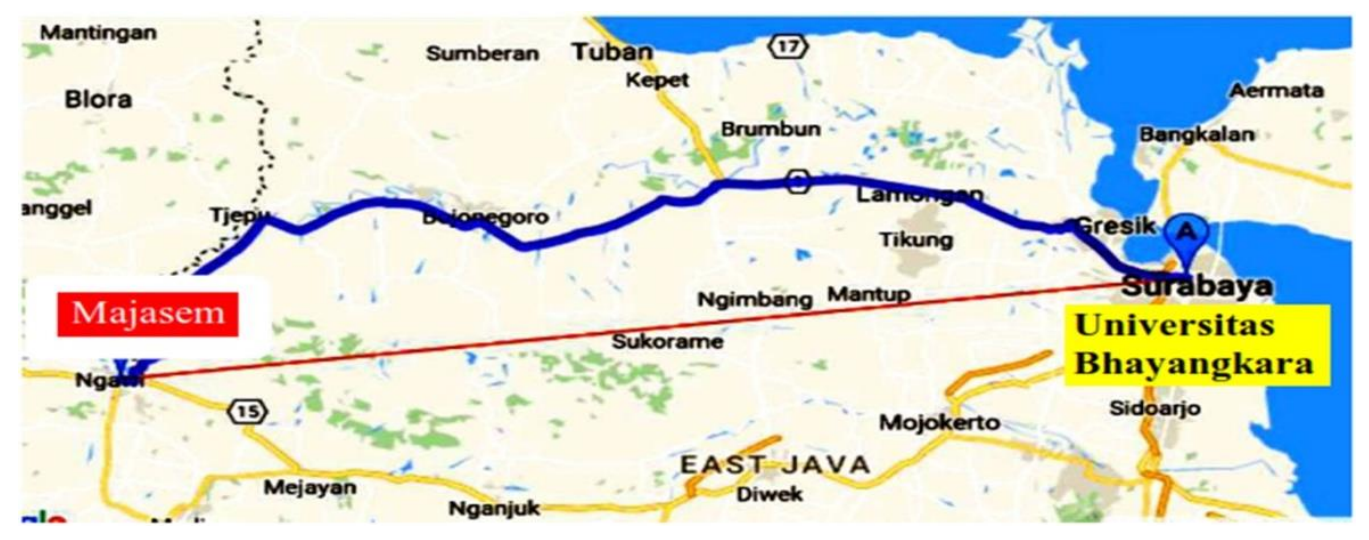

Figure 1. Majasem Village Location

This plant can produce 20-40 tons/ha on considered short time, on 40-60 days period. Every family can produce 6-10 tons of pumpkin with high product quality, with diameter of $18 \mathrm{inch}$. Estimated pumpkin production is 30.000 tons. According to its tophography Majasem village is considered have strategic location because its bypassed by Madiun-Karanganyar Jawa Tengah. So its good to market those pumpkin there. In a year, farmer can harvest up to 4 times, they can produce 180.000 tons or 18.000 units. These can be a potential to increase income of the majasem village by social engineering, art 
intervention, business governance and post harvest technology. (Arfianto \& Balahmar, 2014; Ansari, 2013)

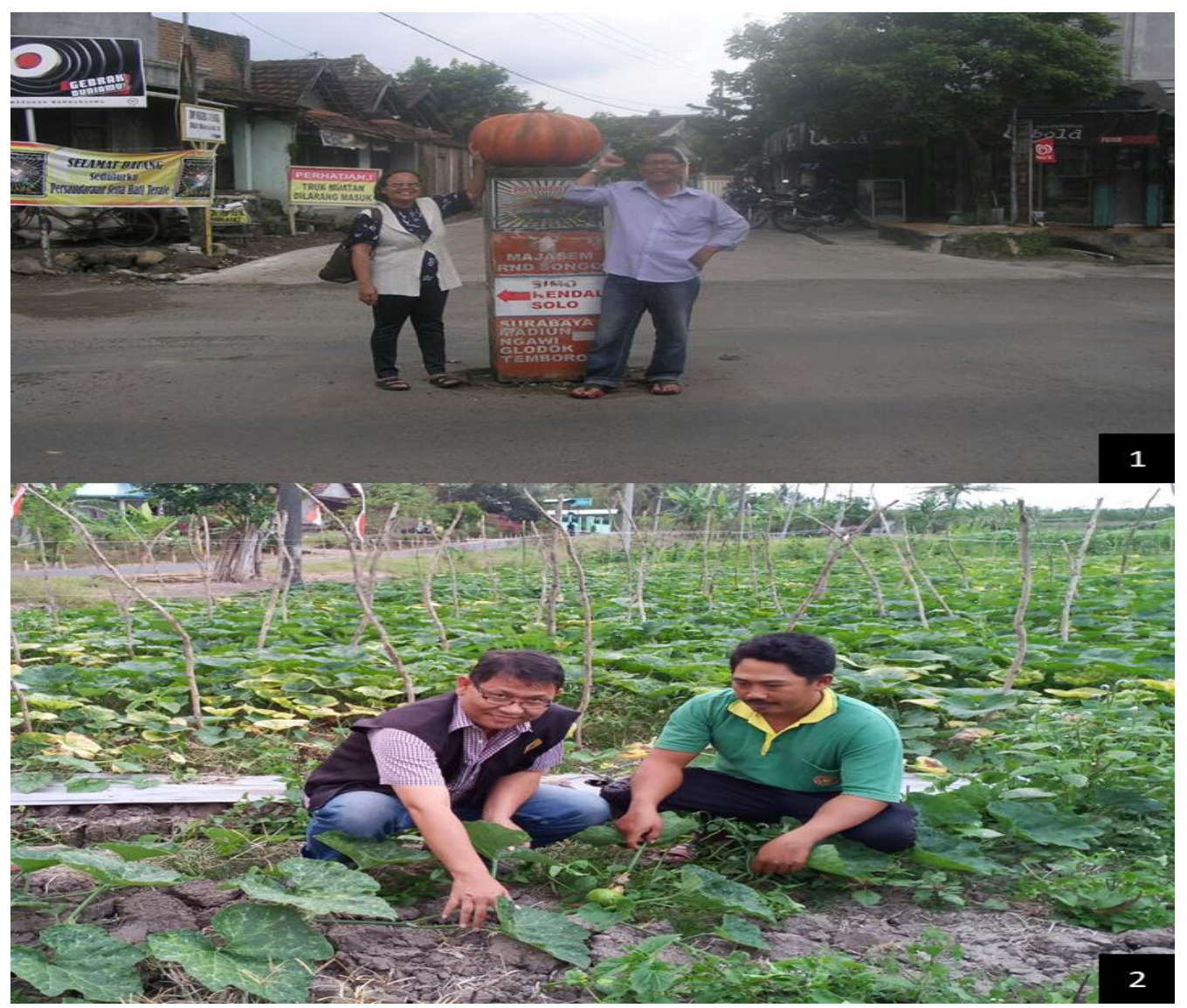

Figure 2. Pumpkin Monument on Majasem Village Main Crossroads (1); Pumpkin Farmland in Majasem Village (2) Majasem Village consist of 6 Sections, 6 RW, 24 RT with area of $14.81 \mathrm{~km}^{2}$, population of 9.342 people with density of $631 \mathrm{person} / \mathrm{km}^{2}$. Farming has become main sector here, Majasem village doesn't have big industrial company. They mainly consist of small home industry and folk crafts. These are representation of social-economy condition of Majasem village.

Table 1. Majasem Village Social-Economy Indicators, Kendal-Ngawi 2019

\begin{tabular}{|c|c|c|c|}
\hline No & Indicator & Total & Information/Activity \\
\hline 1 & BUMDes (unit) & 1 & Loans; Finance Asset IDR 25 millions \\
\hline 2 & Karang Taruna (group) & 6 & Social Community; 197 membership \\
\hline 3 & LMDH (group) & 9 & Agriculture (in Perhutani Area) \\
\hline 4 & PKK (group) & 6 & 3 events/month; group capital (IDR) 25 millions/group \\
\hline 5 & Store/Shop (tenant) & 27 & Open hours at $6 \mathrm{am}-8 \mathrm{pm}$ \\
\hline 6 & $\begin{array}{l}\text { PAD/annual } \\
\text { (IDR) }\end{array}$ & 578.180 .000 & Budget Allocation from Province IDR 62,5 millions \\
\hline 7 & ADD/annual (IDR) & 768.704 .000 & Budget Allocation from Regency IDR 18 millions \\
\hline
\end{tabular}

Source. Government of Majasem Village, Kendal-Ngawi (2019)

\subsection{Pumpkin Business System Profile}

\subsubsection{Pumpkin Cultivation Growth Requirement}

Pumpkin with Cucurbita moshata Durch variety are plant fruit that use vine to grow which classified as Cucurbitaceae family. Pumpkin cultivation can be done on area that have 800-1200 masl. With rainfall of 700-1000 mm/year and have approximate of $75 \%$ humidity. Type of soil for pumpkin cultivation are humus alluvial soil, loose soil on swamp marks, andosol, red soil and grumusol. Acid level on soil on 5,0-6,5 range. And enough sunlight on the field. (Agriculture Department of Magetan Regency, 2015; Kelley \& Langston Jr., 2017) 


\subsubsection{Field Preparation of Pumpkin Cultivation}

Field used to cultivate pumpkin generally need spacious one, because pumpkin growth on vine, growing it in polybag can not yield great result. Field need to be weed free too. Clearing the field can be done either use manual or with tools. Stones that scattered around field need to be removed too. After cleared, the soil on the field need to be tilled, either with hoe or tractor. Next thing are make a bed layout for the pumpkin, the hills should have have 1 meter width and $30 \mathrm{~cm}$ higher than the rest. For the length it depend on the field area. If the area are considered large one, every two beds need to be added with trenches, $40 \mathrm{~cm}$ width are good enough for this irrigation system. Diameter for planting needed for pumpkin normally around $10 \mathrm{~cm}$ and with distance between planting hole is $40 \mathrm{~cm}$. With bed width of $1 \mathrm{~m}$, it can have up to two lane of plant hole. After beds are ready, fertilizer are used on those plant hole. (Agriculture Department of Magetan Regency, 2015; Kelley \& Langston Jr., 2017)

\subsubsection{Pumpkin Mulch Installation}

Mulch used on pumpkin cultivation are used to maintain humidity of soil and to repress the weeds. Mulch installation generally better done during day time, because its easier to stretched out. To create plant hole, hot iron are used to create hole in the mulch. (Agriculture Department of Magetan Regency, 2015; Kelley \& Langston Jr., 2017)

\subsubsection{Planting on Pumpkin Cultivation}

Planting are done on day 6 after soil preparation finished. On every plant holes 2 seeds of pumpkin are planted with 0,5-2 $\mathrm{cm}$ depth. Those seeds need to be covered with husk ash or kitchen ash to prevent snails and worm. After 7 days of planting, the seeds will grow into sprouts. (Agriculture Department of Magetan Regency, 2015; Kelley \& Langston Jr., 2017)

\subsubsection{Treatment on Pumpkin Cultivation}

One specific treatment on pumpkin cultivation is making a trellies for vine to grow. Bamboo or strong woods can be used here, as it need to hold the pumpkin which weighted as $3 \mathrm{~kg}$ and in every plant can have up to 10 pieces. These trellies at least have 2 meters length and plugged in at least 0,5 meters depth. Trellies installation can be done when the vine are not too big. The vine needs to be wrapped on these trellies. This need to be done so vine growth can be controlled to help farmer on treating the pumpkin. Watering can be done depend on the soil and plant needs. Until 7 days of planting, replanting can be done if there are defective seeds. Getting rid of weeds on bedding can be done manually. (Agriculture Department of Magetan Regency, 2015; Kelley \& Langston Jr., 2017)

\subsubsection{Supplementary Fertilizer on Pumpkin Cultivation}

If pumpkin cultivation last up to 3 months, then in each subsequent month, supplementary fertilizer are added. Fertilizer used on pumpkin cultivation is organic manure, the ratio between fertilizer and water are 1:1. Fertilizer sprayed on plant hole and its part with scale of 1 litre for 1 meter area. Organic manure composed of dried and fermented cow or goat dung. Fermentation process took up to 1 week before it can be applied on crop. (Agriculture Department of Magetan Regency, 2015; Kelley \& Langston Jr., 2017)

\subsubsection{Pumpkin Harvesting}

If pumpkin fruit color turn into bright one, it's a sign that pumpkin are ready to be harvested. Toughness on pumpkin skin made it easier to transport, because it can withstand damage during long distance shipping. Dried vine and pumpkin trunk will harden and tools are needed to cut it off during harvesting. Storage used on pumpkin either during shipping or keeping are on dry storage, refrigrater or wet storage only make pumpkin rotten faster unless its already opened. Old pumpkin fruit can be used as additional main food. (Agriculture Department of Magetan Regency, 2015; Kelley \& Langston Jr., 2017)

Crop cultivation is one of few that business that are promising. One of the crop that can be used on this business is pumpkin. To start out pumpkin cultivation business, investment that needed are not that high. It can be done on garden, field or use intercropped pattern. With these pumpkin business are good to various group of peoples. With high will and interest on this business, the benefit are hard to miss. Consument and demand for pumpkin are generally high and processed product from pumpkin have high potential. From home snack industry to cosmetic and pharmacy. (Soekartawi \& Soeharjo, 2011)

In pumpkin cultivation, tools needed are such as; basket, sickle, knife chopper, scale, water pump, water hose, scissor, hoe, cart, bucket, and sprayer. With these tool pumpkin cultivation expected to have good product . On marketing, pumpkin can be sold directly to market, restaurant, or hotel (Kit Yok et al, 2015; Aimi Fadzirul et al, 2018).. Employee needed on this business are generally small at first. Price can fluctuate from IDR 5000/kg up to IDR $11.000 / \mathrm{kg}$, it depends on the market. Based on other crop cultivation, pumpkin are generally profitable business. The weakness on this business are low production rate and productivity level. 
On describing pumpkin cultivation strategy, SWOT analysis are used. Its descriptive based analysis and put situation or condition as input factor. Those factors will be classified based on its contribution. Internal (Strength and weakness) and external (Opportunity and Threats) on SWOT intended at describing condition or situation faced by farmer during cultivation process. On these table are factors that formulated from data and information gathered from farmers.

Table 2. SWOT Analysis on Pumpkin Cultivation Business Kuning on Majasem Village

\begin{tabular}{|c|c|c|}
\hline Exterr & $\begin{array}{l}\text { STRENGTH (S) } \\
\text { 1. Easy to cultivate and farmer are } \\
\text { experienced } \\
\text { 2. Simple skill and trellies needed } \\
\text { 3. High disease tolerant and tough } \\
\text { 4. High need on industry } \\
\text { 5. Public favor organic. }\end{array}$ & $\begin{array}{l}\text { WEAKNESS }(\mathbf{W}) \\
\text { 1. Intercropped plant } \\
\text { 2. Post-harvest limitation } \\
\text { 3. Farmer motivation of marketing } \\
\text { 4. Pumpkin market depend on } \\
\text { season } \\
\text { 5. Industry are consist of small and } \\
\text { micro business. }\end{array}$ \\
\hline $\begin{array}{l}\text { OPPORTUNITY (O) } \\
\text { 1. Product quality can be improved } \\
\text { 2. Product quantity can be } \\
\text { improved } \\
\text { 3. Productivity can be improved } \\
\text { 4. Pumpkin can be commercialized } \\
\text { crop } \\
\text { 5. High market potential on } \\
\text { processed product. }\end{array}$ & $\begin{array}{l}\text { SO Strategies } \\
\text { 1. Commercial production on } \\
\text { industry level } \\
\text { 2. Maintain consument loyality } \\
\text { 3. Expand the market on } \\
\text { post-harvest process, etc. }\end{array}$ & $\begin{array}{l}\text { WO Strategies } \\
\text { 1. Prepare for commercialized crop } \\
\text { 2. Support in funds, technology for } \\
\text { higher product quality on village } \\
\text { basis } \\
\text { 3. Increase promotion to expand } \\
\text { market. }\end{array}$ \\
\hline $\begin{array}{l}\text { THREATS (T) } \\
\text { 1. Rice, corn, soybean crop on } \\
\text { market competition } \\
\text { 2. Unstable supply chain } \\
\text { 3. Supply chain is not considered } \\
\text { on industry level } \\
\text { 4. Lack of market data } \\
\text { 5. Limited field }\end{array}$ & $\begin{array}{l}\text { ST Strategies } \\
\text { 1. To motivate farmers to grow } \\
\text { pumpkin instead of rice, corn and } \\
\text { soybean. } \\
2 \text {. To find information on cross } \\
\text { institution on pumpkin demands to } \\
\text { stabilize the supply chain. } \\
\text { 3. Preparing field to } \\
\text { commercialized pumpkin cultivation } \\
\text { on industry level }\end{array}$ & $\begin{array}{l}\text { WT Strategies } \\
\text { 1. To revamp the mindset of } \\
\text { cultivating rice, corn and soybean into } \\
\text { pumpkin } \\
\text { 2. Create processed product } \\
\text { industry on post-harvest pumpkin, } \\
\text { mainly on micro business } \\
\text { 3. Maintain supply chain with } \\
\text { cropping pattern based on demands of } \\
\text { pumpkin industrialization }\end{array}$ \\
\hline
\end{tabular}

Source. Analysis (2019)

\subsection{Commercialization and Properness of Pumpkin Cultivation Business}

3.1.1 Pumpkin Cultivation Business Analysis Investment

A. Expenses Components 
Table 3. Expenses Components Cost Total

\begin{tabular}{|c|c|c|}
\hline \multicolumn{2}{|l|}{ Expenses } & Cost/Value \\
\hline \multicolumn{3}{|l|}{ 1. Tools } \\
\hline Field Clearing & IDR & 2.014 .000 \\
\hline Pumpkin Seed & IDR & 285.000 \\
\hline Chopper \& Sickle & IDR & 72.500 \\
\hline Hand Sprayer & IDR & 123.000 \\
\hline Hoe & IDR & 137.000 \\
\hline Water Pump & IDR & 224.500 \\
\hline Cart & IDR & 221.500 \\
\hline Weight Scale & IDR & 32.500 \\
\hline Bucket \& Pipe & IDR & 224.000 \\
\hline Pest Spray Machine & IDR & 218.000 \\
\hline Ancillary Equipment & IDR & 27.800 \\
\hline Total Tools Investment & IDR & 3.579 .800 \\
\hline \multicolumn{3}{|l|}{ 2. Monthly Operational Cost (Fixed Cost) } \\
\hline Field Clearing Shrinkage (1/12 × IDR 2.014.000) & IDR & 167.833 \\
\hline Pumpkin Seed Shrinkage (1/62 × IDR 285.000) & IDR & 4.597 \\
\hline Chopper \& Sickle Shrinkage (1/62 × IDR 72.500) & IDR & 1.169 \\
\hline Hand Sprayer Shrinkage (1/62 × IDR 123.000) & IDR & 1.984 \\
\hline Hoe Shrinkage $(1 / 44 \times$ IDR 137.000$)$ & IDR & 3.114 \\
\hline Water Pump Shrinkage (1/62 × IDR 224.500) & IDR & 5.102 \\
\hline Cart Shrinkage $(1 / 62 \times$ IDR 221.500) & IDR & 3.573 \\
\hline Weight Scale Shrinkage $(1 / 62 \times$ IDR 32.500) & IDR & 739 \\
\hline Bucket \& Pipe Shrinkage (1/44 × IDR 224.000) & IDR & 5.091 \\
\hline Pest Spray Machine Shrinkage (1/62 × IDR 218.000) & IDR & 3.516 \\
\hline Ancillary Equipment Shrinkage (1/44 × IDR 27.800) & IDR & 6.950 \\
\hline Worker Wage & IDR & 1.400 .000 \\
\hline Total Monthly Operational Cost (Fixed Cost) & IDR & 1.603 .667 \\
\hline \multicolumn{3}{|l|}{ 3. Variable Cost } \\
\hline Compost Fertilizer (IDR $21.500 \times 30$ ) & IDR & 645.000 \\
\hline Chemical Fertilizer (IDR $21.500 \times 30$ ) & IDR & 945.000 \\
\hline Pesticide (IDR $27.000 \times 30$ ) & IDR & 810.000 \\
\hline Other Cost (IDR $21.600 \times 30)$ & IDR & 648.000 \\
\hline Transportation Cost (IDR $22.000 \times 30)$ & IDR & 660.000 \\
\hline Packer (IDR $20.000 \times 30$ ) & IDR & 300.000 \\
\hline Fuel (IDR $20.000 \times 30)$ & IDR & 600.000 \\
\hline Total Variable Cost & IDR & 4.608 .000 \\
\hline \multicolumn{3}{|l|}{ TOTAL OPERATIONAL COST } \\
\hline $\begin{array}{l}\text { Total Monthly Operational Cost (Fixed Cost) + Total Variable Cost } \\
(1.603 .667+4.608 .000)\end{array}$ & IDR & 6.211 .667 \\
\hline
\end{tabular}

Source: Analysis (2019) 
B. Income

Table 4. Total Income (per Harvest \& Monthly Profit)

\begin{tabular}{l|l|l}
\hline \multicolumn{1}{l|}{ Income } & \multicolumn{2}{l}{ Value } \\
\hline 1. Income per Harvest (30 days) & \multicolumn{2}{l}{} \\
\hline $57 \mathrm{~kg} \times 5.000 \times 30$ & IDR & 8.550 .000 \\
\hline 2. Monthly Profit & & 2.338 .333 \\
\hline $\begin{array}{l}\text { Total Income }- \text { Total Operational Cost } \\
(8.550 .000-6.211 .667)\end{array}$ & \\
\hline
\end{tabular}

Source: Analysis (2019)

3.1.2 Return of Investment

Total Investment/Profit $\rightarrow$ IDR 3.579.800: IDR 2.338.333 = 2 month

With these analysis, the conclusion is pumpkin cultivation business is profitable, which turn IDR 3.579 .800 of investment to IDR 2.338.333 monthly profit on 2 month.

Farms commodity cultivation can't be isolated from farming business and markets. (Budiarto, 2011) Farm business need to be reinforced with marketing activity so the product can be distributed to consument without problem konsumen (Kit Yok et al, 2015; Aimi Fadzirul et al, 2018). Farm markets are commodity flow process with the transfer of ownership on the commodity and creation of time, place, form service on market institution that carry out one or more market functionality. (Rachmania et al, 2016; Arfianto, \& Balahmar, 2014; King et al, 2010) Generally channel pattern on market consisted of 4 pattern, such as; zero-level channel, one-level channel, two-level channel, three-level channel. Channel 1 are three-level channel. This channel the flow of commodity come from farmer through collectors, wholesalers, small traders and consument. Channel IV is zero-level channel, the farmers sell it directly into consument. These table descript the channel on farmer market chain.

Table 5. Market Channel Pattern of Pumpkin

\begin{tabular}{ll}
\hline Market Channel & Supply Chain \\
\hline Channel I & Farmer $\rightarrow$ collectors $\rightarrow$ wholesalers $\rightarrow$ small traders $\rightarrow$ consument \\
Channel II & Farmer $\rightarrow$ wholesalers $\rightarrow$ small traders $\rightarrow$ consument \\
Channel III & Farmer $\rightarrow$ small traders $\rightarrow$ consument \\
Channel IV & Farmer $\rightarrow$ consument \\
\hline
\end{tabular}

Source: Primary Data

On Channel I, the precentage of market margin are the highest, which is $73 \%$ with lowest percentage of farmer's share which is $27 \%$. Channel IV got lowest market margin, $31,42 \%$ but got farmer's share of $68,6 \%$. Channel IV is the most efficient because the commodity does not need to went through lot of instituion on market, which lead to $68,6 \%$ farmer's share and market margin of $31,42 \%$. On other channel the market margin percentage are higher because there are cost on every institution the commodity went. These cost are based on transportation cost, labor wage, retribution, and loading cost.

Table 4. Total Market Cost, Total Market Profit, and Total Market Margin on every Market Channel of Pumpkin

\begin{tabular}{|c|c|c|c|c|c|c|c|}
\hline No & $\begin{array}{l}\text { Market } \\
\text { Channel }\end{array}$ & $\begin{array}{l}\text { Total } \\
\text { (IDR) }\end{array}$ & Cost & $\begin{array}{ll}\text { Total } & \text { Profit } \\
\text { (IDR) } & \end{array}$ & $\begin{array}{l}\text { Total Market } \\
\text { Margin (IDR) }\end{array}$ & $\begin{array}{l}\text { Market } \\
\text { Margin (\%) }\end{array}$ & $\begin{array}{l}\text { Farmer Sharing } \\
\text { Percentage }(\%)\end{array}$ \\
\hline 1 & Channel I & 257,00 & & $4.266,67$ & $7.299,99$ & 73,00 & 27,00 \\
\hline 2 & Channel II & 199,00 & & $9.798,77$ & $10.000,00$ & 66,67 & 47,00 \\
\hline 3 & Channel III & 11,36 & & 4.900 .00 & $4.900,00$ & 49,00 & 51,00 \\
\hline 4 & Channel IV & 0,77 & & $3.065,00$ & $3.141,67$ & 31,42 & 68,6 \\
\hline
\end{tabular}

Source: Primary Data

\section{Discussion}

Pumpkin cultivation profile can be made with Strength and Opportunity (SO), with commercial production on industry level, maintain consument loyality, expand the market on post-harvest process. From weakness and opportunity (WO) 
preparing for commercialized crop, support in funds, technology for higher product quality on village basis, increasing promotion to expand market can be applied. Strategies from strength and threats (ST) are to motivate farmers to grow pumpkin instead of rice, corn and soybean, to find information on cross institution on pumpkin demands to stabilize the supply chain, preparing field to commercialized pumpkin cultivation on industry level. From weakness and threats (WT) strategies needed are to revamp the mindset of cultivating rice, corn and soybean into pumpkin, create processed product industry on post-harvest pumpkin, mainly on micro business, maintain supply chain with cropping pattern based on demands of pumpkin industrialization.

Business properness on commercialized pumpkin need investment of IDR 3.579 .800 and operational cost of IDR 6.211.667 can generate income per harvest up to IDR 8.550 .000 or montly income as IDR 2.338 .333 with return of investment on 2 months. On market supply chain perspective, pumpkin cultivation business divided into 4 channel's pattern. With Channel I have market margin of $73 \%$ and farmer's share of $27 \%$. And channel with most efficiency got $68,6 \%$ farmer's share and only $31,42 \%$ market margin, which is Channel 4 . This happen because the supply chain follow few institution on commodity flow. On Channel 4 the commodity come from farmer and directly sold to consument. This reduce cost on supply chain line.

\section{Acknowledgement}

To Director's of Research and Community Service Ministry of Research and Technology as a funding support institution on this research. Moreover to the partys that helps on this research. A thank you to Ngawi Regency Government, c.q Village Leader, Village Officials and people of Majasem Village, Kendal, Ngawi on giving information and primary data and secondary data.

\section{References}

Agusta, I. (2014). Indeks Kemandirian Desa Metode, Hasil dan Alokasi Program Pembangunan. Jakarta: Yayasan Pustaka Obor.

Ahmad, G., \& Khan, A. A. (2019). Pumpkin: Horticultural Importance and Its Roles in Various Forms; a Review. International Journal of Holticulture \& Agriculture, 4(1), 1-6. http://dx.doi.org/10.15226/2572-3154/4/1/00124

Aimi, F. K., Asmaddy, H., Siti Nrazira, M. D., Zurina, K., Nursilah, A., Nurul, A. M., \& Syadiyah, A. S. (2018). The Potential of Pumpkin (Cucurbita Moschata Duschene) as Commercial Crop in Malaysia. Pertanika Journal of Scholarly Research Reviews, 4(3), 1-10.

Ansari, B. (2013). Sustainable Entrepreneurship in Rural Areas. Research Journal of Environmental and Earth Science, 5(1), 26-31. https://doi.org/10.19026/rjees.5.5635

Ardhyani, R., Rahayu, W., Sundari, M. T. (2016). Analisis Pemasaran Labu Kuning (Cucurbita Moschata D.) di Kecamatan Plaosan Kabupaten Magetan Jawa Timur. Agrista, 4(1), 57-67.

Arfianto, A. E. W., \& Balahmar, A. R. U. (2014), Pemberdayaan Masyarakat dalam Pembangunan Ekonomi Desa. Kebijakan dan Manajemen Publik, 2(1), 47-56.

Budiarto, S. (2011). Pemasaran Industri. Yogyakarta: Penerbit Andi.

Dinas, P. K. M. (2015). Standar Operasional Prosedur (SOP) Labu Kuning. Magetan.

Dugguh, S. I., Aki, I., \& Oke, S. (2018). Impact of Growth Strategies on Business Profit A Study of Ashakacem Plc, Gombe-Nigeria. Journal of Business and Management, 20(2), 23-29.

Gardjito, M. (2006). Labu Kuning Sumber Karbohidrat Kaya Vitamin A. Yogyakarta: Tridatu Visi Komunika.

Gürel, E., \& Tat, M. (2017). SWOT Analysis: A Theoretical Review. The Journal of International Social Research, 10(52), 994-1006. https://doi.org/10.17719/jisr.2017.1832

Hedrasty. (2011). Kandungan Labu Kuning dan Pemanfaatannya. Yogyakarta: Penerbit Kanisius.

Horne, J. C. V., \& Wachowicz, J. M. (2013). Prinsip-Prinsip Manajemen Keuangan. Jakarta: Salemba Empat.

Hwa, K. J. L., Taip, F. S., Ibrahim, M. N., Aziz, N. A., \& Shishir, M. R. I. (2016). Effect of Pre-Treatment on the Physical Properties of Pumpkin Powder. Australian Journal of Basic and Apllied Sciences, 10(7), 146-151.

Iwo, M. I., Insanu, M., \& Dass, C. A. S. (2014). Development of Immunonutrient from Pumpkin (Cucurbita moschata Duchense Ex. Lamk.) Seed. Procedia Chemistry, 13, 105-111. https://doi.org/10.1016/j.proche.2014.12.013

Kelley, W. T., \& Langston, J. D. B. (2017). Commercial Production and Management of Pumpkins and Gourds. Retrieved from http://extension.uga.edu/publication

King, R. P., Hand, M. S., DiGiacomo, G., Clancy, K., Gómez, M. I., Hardesty, S. D., .. McLaughlin, E. W. (2010). 
Comparing the Structure, Size, and Performance of Local and Mainstream Food Supply Chains. US: Department of Agriculture. Economic Research Service. (accessed December 2019)

Kit Yok, M. C., Gisong, S. A. D., Modon, A. B., \& Rusim, R. (2015). Creating New Market in Integrated Agriculture Development Area in Samarahan, Sarawak, Malaysia - Case Study in the Supply Chain of Cucurbita sp. (Pumpkin). Procedia-Social and Behavioral Science, 224, 516-522. https://doi.org/10.1016/j.sbspro.2016.05.428

Negi, S., \& Anand, N. (2015). Issues and Challenges in The Supply Chain of Fruits \& Vegetables Sector in India: A Review. International Journal of Managing Value and Supply Chains (IJMVSC), 6(2), 47-62. https://doi.org/10.5121/ijmvsc.2015.6205

Perez-Meza, J. C., \& Galdeano-Gomez, E. (2010). Agrifood Cluster and Transfer of Technology in The Spanish Vegetables Exporting Sector: The Role of Multinational Enterprises. Agric Econ-Czech, 56(12), 478-488. https://doi.org/10.17221/111/2009-AGRICECON

Pitono, A., \& Kartiwi. (2016). Penguatan Pemerintahan Desa dan Kelurahan Menuju Pembangunan Berkelanjutan Dalam Rangka Peningkatan Kesejahteraan Masyarakat. Jurnal Politikologi, 3(1), 27-37.

Pongjanta, J., Naulbunrang, A., Kawngdang, S., Manon, T., \& Thepjaikat, T. (2006). Utilization of Pumpkin Powder in Bakery Products. Songklanakarin Journal Science Technology, 28(1), 71-79.

Rangkuti, F. (2013). SWOT Balanced Scorecard. Jakarta: Kompas Grameia.

Shahidan, N., Irwandi, J., Othman, R., \& Zuhanis, Y. H. H. (2014). Carotenoid Content in Different Locality of Pumpkin (Cucurbita Moschata) In Malaysia. International Journal of Pharmacy and Pharmaceuticl Sciences, 6(3), 29-32.

Sidik, F. (2015). Menggali Potensi Lokal Mewujudkan Kemandirian Desa. Kebijakan dan Administrasi Publik, 19(2), 115-131. https://doi.org/10.22146/jkap.7962

Singarimbun, M., \& Effendi, S. (2008). Metode Penelitian Survai. Jakarta: LP3ES.

Soekartawi, \& Soeharjo, A. (2011). Ilmu Usaha Tani dan Penelitian untuk Pengembangan Petani Kecil. Jakarta: Penerbit Universitas Indonesia.

\section{Copyrights}

Copyright for this article is retained by the author(s), with first publication rights granted to the journal.

This is an open-access article distributed under the terms and conditions of the Creative Commons Attribution license (http://creativecommons.org/licenses/by/4.0/). 